CORRECTION

\title{
Correction: p63 suppresses the ability of pregnancy-identified mammary epithelial cells (PIMECs) to drive HER2-positive breast
} cancer

Christopher E. Eyermann, Jinyu Li and Evguenia M. Alexandrova (D)

(c) The Author(s) 2021

Cell Death and Disease (2021)12:658; https://doi.org/10.1038/s41419-021-03916-0

Correction to: Cell Death and Disease https://doi.org/10.1038/ s41419-021-03795-5, published online 22 May 2021

The original version of this article unfortunately contained a mistake in the title. The correct title should read "p63 suppresses the ability of pregnancy-identified mammary epithelial cells (PIMECs) to drive HER2-positive breast cancer". The authors apologise for the error. The original article has been corrected.

Open Access This article is licensed under a Creative Commons Attribution 4.0 International License, which permits use, sharing, adaptation, distribution and reproduction in any medium or format, as long as you give appropriate credit to the original author(s) and the source, provide a link to the Creative Commons license, and indicate if changes were made. The images or other third party material in this article are included in the article's Creative Commons license, unless indicated otherwise in a credit line to the material. If material is not included in the article's Creative Commons license and your intended use is not permitted by statutory regulation or exceeds the permitted use, you will need to obtain permission directly from the copyright holder. To view a copy of this license, visit http://creativecommons. org/licenses/by/4.0/.

(c) The Author(s) 2021 